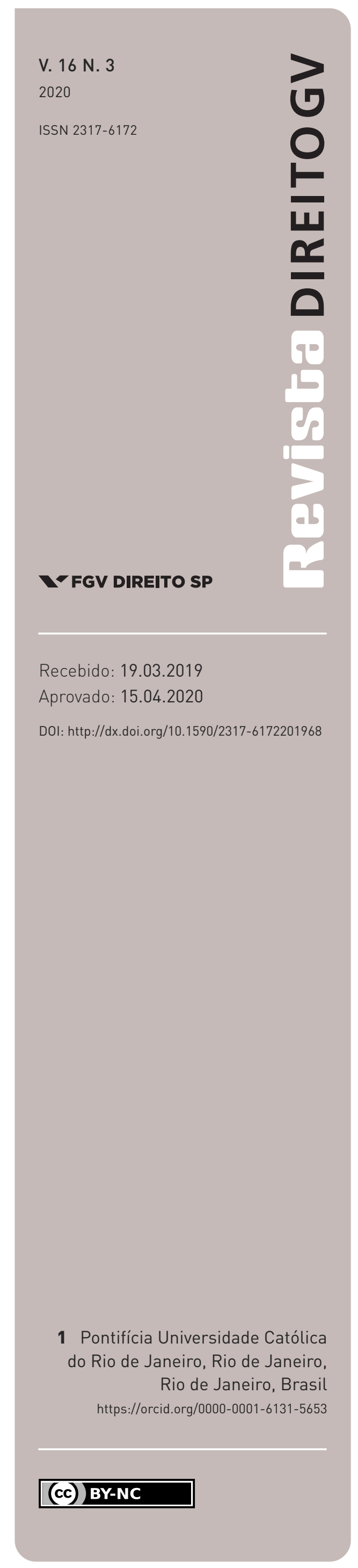

\title{
Questões de raça na luta contra a violência de gênero: processos de subalternização em torno da Lei Maria da Penha
}

\author{
QUESTIONS RELATED TO RACE IN THE STRUGGLE AGAINST GENDER VIOLENCE: \\ SUBALTERNITY PROCESSES RELATED TO THE MARIA DA PENHA LAW
}

Márcia Nina Bernardes ${ }^{1}$

\section{Resumo}

A Lei Maria da Penha (LMP) constitui uma enorme conquista na luta pela paridade de gênero. 0 processo social que resultou na LMP alterou significativamente os termos em que se discutia violência doméstica no país, permitindo que o tema saísse das rodas de especialistas e se transformasse em um ponto importante de debate na esfera pública. No entanto, seus resultados têm sido diversos em relação a diferentes corpos de mulheres. Pesquisas sobre a efetividade da lei mostram que ela tem servido para diminuir a incidência da violência contra mulheres brancas, mas não tem surtido o mesmo efeito para a proteção das mulheres negras. A partir de lentes teóricas fornecidas pelos feminismos negros e dos feminismos pós e decoloniais, pode-se afirmar que a mulher negra vítima de violência é subalternizada, e, neste artigo, é discutido qual o papel da militância e do sistema de justiça nesse processo de subalternização. A intenção é, por um lado, de problematizar - em vez de condenar - estratégias do movimento feminista hegemônico brasileiro na formulação e na fiscalização da lei que contribuem para a reprodução da hierarquia entre as mulheres. Por outro lado, busca-se evidenciar como o Judiciário funciona de modo a manter as hierarquias raciais nas questões de violência de gênero.

\section{Palavras-chave}

Violência de gênero; racismo; subalternidade; Lei Maria da Penha; sistema de Justiça.

\begin{abstract}
The Maria da Penha Law (MPL) constitutes a great achievement in the struggle for gender parity. The social process that resulted in the MPL significantly altered the terms in which domestic violence was discussed in the country, allowing the issue to leave the circle of experts and become an important point of debate in the public sphere. However, its results have been diverse with respect to different women's bodies. Data show that the law has served to decrease the incidence of violence against white women, but it has not had the same effect for the protection of black women. Relying on theoretical framework provided by black feminisms and decolonial/postcolonial feminisms, this article presents contends that black women who are victims of violence have been subalternized and silenced, and it discusses the role which the hegemonic feminism and the judicial system play in this process. The intention, on one hand, is to problematize, rather than condemn, strategies of the Brazilian hegemonic feminist movement in the formulation and enforcement of this law, which contribute to the reproduction of hierarchies amongst women. On the other hand, this paper also aims to evidence how the judicial system functions in order to maintain racial hierarchies in questions related to gender violence.
\end{abstract}

\section{Keywords}

Gender violence; racism; subalternity; Maria da Penha Law; Judicial system. 


\section{INTRODUÇÃO}

A Lei n. 11.340 (Lei Maria da Penha, doravante LMP), promulgada em 7 de agosto de 2006, visando combater o fenômeno da violência doméstica contra as mulheres, certamente constitui uma enorme conquista na luta pela paridade de gênero. Entre outras inovações, a sistemática inaugurada com a lei destaca a importância da prevenção, e não apenas da repressão, afirma o caráter interdisciplinar do problema e aperfeiçoa o sistema judicial para que a resposta estatal venha com mais efetividade e proteção às vítimas, e as ações penais possam de fato resultar em condenações, quando for o caso. O processo social que resultou na LMP alterou significativamente os termos em que se discutia violência doméstica no país, permitindo que o tema saísse das rodas de especialistas e se transformasse em um ponto importante de debate na esfera pública. Alguns de seus grandes legados são a disseminação da mensagem de que violência contra as mulheres não é crime de menor potencial ofensivo, mas, sim, violação grave de direitos humanos, e o consequente empoderamento de mulheres para reagir e denunciar a violência sofrida. Apesar de a subnotificação das ocorrências de violência ainda ser uma realidade dura de superar, após a lei, há um notável aumento de denúncias, o que nos permitiu dimensionar melhor o tamanho do problema no país. Segundo relatório da Geledés - Instituto da Mulher Negra:

A Lei Maria da Penha representou enorme avanço na exigibilidade de atuação pública no enfrentamento à violência contra a mulher, pois além de tipificar, definir e estabelecer as formas da violência doméstica contra a mulher, determinando a criação de juizados especiais de violência doméstica e familiar contra a mulher com competência cível e criminal, estabeleceu medidas de assistência e proteção e atendimento humanizado às mulheres e criou mecanismos para coibir a violência e proteger as vítimas. A Lei determinou que o poder público desenvolvesse políticas para garantir os direitos humanos das mulheres no âmbito das relações domésticas e familiares, no sentido de resguardá-las de toda forma de negligência, discriminação, exploração, violência, crueldade e opressão. (CARNEIRO, 2017, p. 33)

No entanto, pesquisas mostram que seus resultados têm sido diversos em relação a diferentes corpos de mulheres. Estudo do Instituto de Pesquisa Econômica Aplicada (Ipea) em 2015 avaliou a efetividade da lei a partir da evolução dos números relativos a homicídios de mulheres no país. Apesar de a lei não tratar diretamente do feminicídio, ao se propor intervir no ciclo de violência intrafamiliar e doméstica "onde muitas vezes há um acirramento no grau de agressividade envolvida, que, eventualmente, redunda (muitas vezes de maneira inesperada) na morte do cônjuge", presume-se que a lei "gere também um efeito de segunda ordem para fazer diminuir os homicídios ocasionados por questões domésticas e de gênero" (IPEA, 2015, p. 10). Os resultados indicam que a LMP fez diminuir em cerca de 10\% a taxa de homicídios de mulheres dentro das residências, a partir de uma comparação com 
a taxa de homicídios de homens nas mesmas condições. ${ }^{1}$ Em outras palavras, a lei reduziu a velocidade de crescimento do número de homicídios de mulheres no Brasil. Os autores ressaltam que a efetividade não se deu de maneira uniforme no país, por causa dos "diferentes graus de institucionalização dos serviços protetivos às vítimas de violência doméstica” (IPEA, 2015 , p. 20). Onde os serviços da rede de atendimento, bem como os especializados da Defensoria, do Ministério Público e de delegacias, funcionaram melhor, a taxa regrediu em proporções maiores do que nos lugares onde esses serviços não existiam ou não funcionavam adequadamente. Esses dados, contudo, não foram produzidos incorporando critérios sociodemográficos das vítimas. Sabemos que a falta de serviços adequados, que impacta negativamente os resultados da LMP, afeta certas populações com mais intensidade do que outras. Os critérios de raça, classe e região (rural ou urbana, Sul e Sudeste ou Norte e Nordeste, etc.) são decisivos nessa análise.

No mesmo sentido, dados do Mapa da Violência 2015 mostram que a violência contra mulheres brancas diminuiu desde 2003, mas a incidência da violência contra as mulheres negras aumentou nesse mesmo período. De acordo com os dados do Mapa, entre 2003 e 2013, o feminicídio de mulheres brancas caiu 9,8\%, enquanto o de mulheres negras aumentou 54\%. A promulgação da LMP, em 2006, não alterou significativamente esses dados (CARNEIRO, 2017 , p. 33). Tomando a data de entrada em vigor da lei como termo inicial, o número de vítimas brancas caiu 2,1\%, e o de vítimas negras aumentou 35\%. Ainda segundo essa mesma pesquisa, em 2013, a taxa de homicídio de mulheres negras é 66\% maior do que a de mulheres brancas. Por fim, os dados mostram que mulheres são assassinadas em especial em contextos de violência doméstica, mas não exclusivamente (WEISELFISZ, 2015). ${ }^{2}$

1 A pesquisa feita pelo Ipea realizou uma comparação com a taxa de homicídios de homens dentro de casa, que continuou crescente, enquanto a taxa para as mulheres permaneceu no mesmo nível. Os dados apresentados pelo Ipea demonstravam que o assassinato de mulheres dentro de casa era 1,1 para cada 100 mil habitantes em 2006, e depois 1,2 para cada 100 mil no ano de 2011. E as mortes violentas de homens dentro de casa passaram de 4,5 para cada 100 mil em 2006 para 4,8 a cada 100 mil em 2011 (IPEA, 2015, p. 10).

2 O dossiê preparado pelas ONGs Criola (Rio de Janeiro) e Geledés - Instituto da Mulher Negra (São Paulo), para apresentação na Comissão Interamericana de Direitos Humanos acerca da situação da mulher negra no Brasil, sintetiza os números impressionantes da violência contra mulheres negras no país: "No Brasil, os assassinatos de mulheres negras tiveram um aumento de 54,2\% em 10 anos (2002-2013). No mesmo período, houve redução de 9,3\% dos assassinatos de mulheres brancas. No período 2011-2013, 16 mulheres morreram assassinadas por dia, 488 por mês, 5.860 por ano. 45\% eram mulheres jovens (10 a 29 anos). As taxas de homicídios de mulheres foram mais altas nas Regiões Centro-Oeste (7,81\%), Nordeste $(7,31 \%)$ e Norte $(7,26 \%)$ - entre elas, a maioria era negra. As taxas das regiões Sudeste (4,82\%) e Sul (4,26\%), foram também extremamente altas. Em todas as regiões, as mulheres negras foram as principais vítimas de assassinatos, à exceção da Região Sul: 87\% no Nordeste, 81\% no Norte, 71\% no CentroOeste, 55\% no Sudeste e 18\% no Sul. A taxa de homicídios de mulheres negras em todo o país é 2,25 vezes mais alta do que a taxa de homicídios de mulheres brancas" (WERNECK e IRACI, 2016, p. 15). 
Segundo dados do Atlas da Violência do Ipea (2019), mulheres negras foram 66\% das vítimas de homicídio e 61\% das vítimas de feminicídio em 2017. A taxa de homicídios de mulheres negras cresceu 29,9\% entre 2007 e 2017, enquanto a de mulheres brancas cresceu 4,5\% no mesmo período (IBGE, 2018). Segundo essa pesquisa, esses dados, contudo, podem significar tanto o aumento da violência ou a diminuição da subnotificação, com o aprendizado gradativo das instituições de atendimento e de investigação, após a LMP (IPEA, 2019, p. 37-40).

Com relação às inovações e aos serviços criados pela lei, diversos diagnósticos constatam que ela vem sendo aplicada restritivamente, comprometendo em muito suas promessas. ${ }^{3} \mathrm{De}$ modo geral, há prevalência de aplicação de seus dispositivos repressivos e quase total inoperância dos dispositivos de natureza preventiva. ${ }^{4}$ Entre as muitas formas de medidas protetivas de urgência (MPU) previstas em diferentes artigos da lei, apenas aquelas de natureza penal têm sido reiteradamente utilizadas. Somente alguns estados da federação implantaram os juízos com competência cível e criminal. A rede de proteção da mulher - serviços de saúde, abrigamento e capacitação - nunca chegou a ser devidamente implantada, e agora vem sendo desarticulada com rapidez (IPEA, 2015, p. 12). Por fim, a transformação do crime de lesão corporal leve em ação penal pública incondicionada, que independe do consentimento da vítima e impede a aplicação do instituto da suspensão condicional do processo, ainda hoje gera polêmicas em setores conservadores e também progressistas. ${ }^{\mathbf{5}}$ Como resultado desse conjunto, a possibilidade de cárcere para o agressor, ou ao menos de sua condenação criminal, acabou se tornando a

3 Relatório final da Comissão Parlamentar Mista de Inquérito que investigou a situação da violência contra a mulher no Brasil e apurou denúncias de omissão por parte do poder público com relação à aplicação de instrumentos instituídos em lei para proteger as mulheres em situação de violência. Publicado em julho de 2013. Disponível em: http://www.mulher.df.gov.br/wp-conteudo/uploads/2017/11/ CPMI-da-Violência-Contra-a-Mulher-Análise-e-Recomendações-ao-DF-Relatório-final.pdf. Acesso em: 24 set. 2020.

4 Essa constatação alimentou a crítica a um suposto caráter punitivista da LMP, equiparando-a a outras manifestações do estado penal seletivo, que inegavelmente massacra populações subalternizadas (pobres e negros). Subscrevo à denúncia da captura da lei pela da lógica penal na aplicação judicial, mas entendo que leis conquistadas pelos próprios movimentos sociais - como a LMP, a lei contra o racismo e, se aprovada, a lei contra a homofobia - não podem ser incluídas apressadamente nesse contexto. Como diria Nancy Fraser, incluí-las seria adicionar "insulto a ofensa": quando populações que são em geral massacradas pelo Estado conseguem finalmente se apropriar de aspectos do direito penal em seu benefício, são chamadas de punitivistas e conservadoras. Carmen Hein Campos (2017) fala da necessidade de realizarmos um giro paradigmático na interpretação da lei, para além do direito penal, explorando os demais potenciais dela. Rodrigo Costa e Adriana Oliveira (2014) mostram como a lei, mesmo com a interpretação restritiva e repressiva que vem recebendo, aumentou apenas marginalmente a população carcerária.

5 Como crítica progressista a essa inovação, ver Flauzina (2015). 
principal resposta do Estado à violência doméstica. Isso pode ser muito importante simbolicamente, ainda que a LMP não tenha aumentado de modo significativo a população carcerária brasileira, mas também é problemático, como veremos ao longo deste artigo. ${ }^{6}$

Essas constatações colocam em xeque a relevância da lei no combate à violência de gênero contra mulheres negras e de periferias. Afinal, segundo o Mapa, apesar das insuficiências elencadas, a lei tem servido para diminuir a incidência da violência contra mulheres brancas, mas não tem surtido o mesmo efeito para a proteção das mulheres negras. De fato, como ressaltam Werneck e Iraci:

Apesar de o Brasil ter se empenhado nas últimas décadas em ações de diminuição das desigualdades sociais e de enfrentamento da violência contra a mulher, elas não impediram o aumento de 54,2\% dos assassinatos de mulheres negras entre 2003-2013. (WERNECK e IRACI, 2016, p. 5)

Os feminismos transnacional e brasileiro lutaram por décadas para que os direitos das mulheres fossem compreendidos como direitos humanos, e, nessa luta, a discussão sobre violência de gênero se tornou uma das mais importantes e mais consensuais na agenda dos diversos movimentos feministas. Universalizou-se o problema da violência doméstica como um problema de mulheres, mas a dimensão racial da violência contra mulheres não foi devidamente abordada:

[...] como é possível que o racismo, a discriminação racial e a violência racial permaneçam como tema periférico no discurso, na militância e em boa parte das políticas sobre a questão da violência contra a mulher? Só podemos atribuir isto à conspiração de silêncio que envolve o tema do racismo em nossa sociedade e à cumplicidade que todos partilhamos em relação ao mito da democracia racial e tudo o que ele esconde. Historicamente, as políticas públicas para mulheres no Brasil partem de uma visão universalista e generalizante de mulher, incapaz desse simples questionamento, afinal que cara têm as mulheres deste país? (CARNEIRO, 2003, p. 15-16) ${ }^{7}$

Neste artigo, pretendo refletir se as categorias "gênero" e "mulher" são úteis para a análise da opressão se não estiverem, desde o início, problematizadas a partir do racismo e de outros eixos de opressão estrutural. Em referência especificamente à violência de gênero,

6 Sobre o impacto da LMP sobre a população carcerária, ver Costa e Oliveira (2014).

7 Suelaine Carneiro listou diversos artigos de mulheres negras discutindo a relação entre racismo e violência de gênero (CARNEIRO, 2017, p. 26 e 30). 
busco pensar: como a política pública brasileira reproduz a distribuição racializada de privilégios a brancos e de opressões a não brancos? Essa pergunta, em minha análise, foi abordada a partir da discussão de duas outras questões. Com relação às estratégias do feminismo hegemônico (e branco), que lutou arduamente pela aprovação da LMP, em que momentos o racismo estrutural, do qual ninguém está isento, operou para a manutenção das hierarquias raciais, instrumentalizando e silenciando a mulher negra vítima de violência doméstica? Por fim, de que forma o sistema judiciário, na implementação cotidiana da lei, participa dessas dinâmicas de subalternização? ${ }^{8}$

As perguntas que guiam a reflexão neste artigo inspiram-se na discussão de Gayatri Spivak sobre subalternidade, como a posição social daqueles cujas vozes não podem ser ouvidas por razões estruturais. Entendo que mulheres negras vítimas de violência são subalternizadas no movimento feminista hegemônico e no sistema de Justiça em torno da LMP. Da mesma forma, levo em consideração a advertência de Spivak a intelectuais que pretendem refletir diretamente a posição daqueles que julgam representar, como se fossem eles mesmos transparentes. Não sou transparente e não pretendo representar a mulher negra subalternizada, mas, ao discutir a LMP, busco refletir sobre as condições de produção da subalternidade que impede certos corpos de serem escutados e de ocuparem posições paritárias em sociedades ditas democráticas (SPIVAK, 2010; ALMEIDA, 2010).

O artigo está estruturado em quatro seções. A primeira é de caráter mais epistemológico, e as duas seguintes, explicitamente voltadas para as questões políticas em torno do desenho da LMP e de sua implementação pelo Judiciário. O exercício aqui é de análise crítica e interpretativa (HALL, 2012) de dados empíricos obtidos em outras pesquisas, sob as lentes desenvolvidas na primeira seção. Assim, na seção inicial, busco explorar as lentes epistemológicas que afetam a formulação e a aplicação de políticas públicas a partir de argumentos formulados pelos feminismos negros, decoloniais e pós-coloniais. Enfrento a discussão sobre o racismo estrutural do patriarcado e a imbricação inexorável entre raça e gênero nas experiências de vítimas de violência de gênero. Os conceitos de subalternidade de Spivak (2010) e de colonização do saber, como utilizado por Maria Lugones (2014), são fundamentais nesta análise. Partilho do entendimento de que as diferenças de representação das mulheres negras e das brancas suscitam questões importantes relativas aos contornos, ao conteúdo e às possibilidades de significação da categoria "mulher" e permitem, também, que desloquemos a mulher branca da posição de sujeito universal do feminismo para pensá-la racialmente.

8 É importante também esclarecer que não pretendo “essencializar” o feminismo negro ou o feminismo branco. Entendo que são ambas as posições/identidades políticas e relacionais, com fronteiras nebulosas e cambiantes. Como ensina Avtar Brah (2006, p. 331): "[...] os feminismos negro e branco não devem ser vistos como categorias essencialmente fixas e em oposição, mas antes como campos historicamente contingentes de contestação dentro de práticas discursivas e materiais”. 
Na seção seguinte, refiro-me explicitamente à LMP como centro da política pública brasileira contra violência de gênero. Recorro à pesquisa conduzida pela Geledés - Instituto da Mulher Negra com funcionárias e usuárias de cinco centros da rede de atendimento a mulheres da cidade de São Paulo, e à distinção entre "resistência" e "militância" feita por Ana Flauzina para problematizar estratégias do feminismo hegemônico que acabaram por silenciar mulheres negras vítimas de violência. Os conceitos de sobreinclusão e subinclusão de Kimberlé Crenshaw fornecem as ferramentas analíticas apropriadas para revelar as formas como o racismo operou nessas dinâmicas. Seguindo o exemplo de Ana Flauzina (2015, p. 126), a intenção é a de problematizar, em vez de condenar, escolhas do movimento feminista hegemônico brasileiro na formulação e na fiscalização da lei. Entre essas escolhas, destaco a ênfase no Judiciário como ator estatal protagonista dessa luta e a insuficiente atenção às questões de prevenção à violência e de empoderamento da vítima.

Finalmente, na última seção, atento para outros modos de sobreinclusão e subinclusão da mulher negra vítima de violência, desta vez no contexto de aplicação judicial da lei em casos concretos. Com o olhar desenvolvido nas seções anteriores, revisito dados obtidos em duas outras pesquisas com jurisprudência em Juizados de Violência Doméstica e Familiar contra as Mulheres no Rio de Janeiro (BERNARDES, COSTA e OLIVEIRA, 2016; BERNARDES e ALBUQUERQUE, 2016). Entendo que os achados dessas pesquisas podem ser interpretados como reveladores das formas como os corpos das mulheres negras vítimas de violência não "cabem" na prática judicial de diferentes formas, notadamente no enquadramento do que é relevante no âmbito jurídico e no tipo de remédio oferecido.

É importante destacar que a crítica neste artigo não se dirige à LMP como um todo, que considero ser um importante marco de proteção às mulheres. Abrir mão dessa lei, principalmente no contexto atual de retrocesso conservador, seria jogar fora o bebê com a água do banho. Sustento, contudo, que ela precisa ser repensada com urgência, de modo a conferir maior protagonismo à vítima da violência.

\section{RACIALIZANDO O GÊNERO DA VIOLÊNCIA}

Racismo e sexismo, assim como classismo, são dimensões estruturais da vida social e, como tais, forjam subjetividades e posicionam indivíduos socialmente. Negros e brancos, homens e mulheres, nesse sentido, são constituídos nas interações sociais a partir de dispositivos de poder - como nos ensinou Michel Foucault (2001) - que escapam ao controle individual, como a disciplina e a sexualidade. ${ }^{9}$ Em um marco pós-estruturalista, a consciência humana

9 Judith Butler (2015, p. 18-19, 2009, 2006) fala da precariedade como condição definidora da existência: todos os seres viventes são vulneráveis à privação, a ofensas, a lesões à integridade física e à morte 
é atravessada e formada por discursos de poder cambiantes que "falam por nós". Não somos soberanos na formação de nossa subjetividade e de nossa identidade. No entanto, esse processo de subjetivação não ocorre de modo simétrico, e os corpos são hierarquizados a partir da raça e do gênero, além de outros marcadores, facilitando ou impedindo o acesso aos recursos materiais e simbólicos. Nos termos de Lúcia Xavier (2020), uns são agraciados com "mais vida" em detrimento de outros, que têm "menos vida". Se essa distribuição desigual de acesso a recursos para uma vida vivível não for levada em consideração, todas as vezes em que nos utilizamos de linguagem e estratégias “inclusivas” e universalizantes, estamos contribuindo para processos de subalternização.

Pelo menos desde o trabalho de Simone de Beauvoir, o feminismo hegemônico denuncia a figura do sujeito universal como excludente. Esse sujeito abstrato, sem corpo, seria os homens, que funcionam como réguas para a formulação das instituições públicas. As mulheres em sociedades patriarcais são constituídas como o "outro", como objetos, vistas a partir de seus corpos, que, no entanto, não são delas: servem ao olhar dos homens (BEAUVOIR, 1967). Feministas negras denunciam há ainda mais tempo que a "branquitude"10 operou o mesmo truque de poder: apenas os corpos negros são marcados, apenas eles têm raça e são subordinados ao sujeito branco. Nessa dinâmica racial de poder, a categoria "mulher" funciona como substituta do sujeito universal, permitindo que mulheres marcadas racialmente sejam objetificadas e subalternizadas:

O indivíduo abstrato é da ordem da branquitude, como uma racialidade não nomeada. Para sujeitos não brancos, como Fanon nos ensina em relação ao esquema corporal, histórico-racial, do sujeito negro, sua subjetividade é deslocada através de olhares alheios e assim não reconhecida em seus próprios termos; ou seja, através desses

em virtude de processos que não controlamos. Somos todos também inexoravelmente dependentes de interações com serviços de infraestrutura sociais e institucionais para termos o que ela chama de "vida vivível”. No entanto, a autora também destaca que as condições de precariedade não são igualmente distribuídas no globo e certos corpos são mais expostos à privação e à violência do que outros. Se essa distribuição desigual não for levada em consideração, todas as vezes em que nos utilizamos de linguagem e estratégias "inclusivas" e universalizantes, estamos contribuindo para processos de subjugação.

"Branquitude" é um termo utilizado para falar de uma estrutura de poder que organiza corpos e distribui privilégios e ônus a partir de critérios raciais. O ganho teórico que essa expressão nos oferece, em comparação ao termo "racismo", é o de que ela permite a racialização e a implicação daqueles que são privilegiados em uma ordem racializada, deslocando-os da posição de sujeito universal e “neutro". Neste artigo, contudo, não me utilizarei da "branquitude" como categoria. No Brasil, essa discussão tem como pioneiro Guerreiro Ramos, e contemporaneamente vem sendo desenvolvida por Lourenço Cardoso (2010), Aparecida Bento e Iray Carone (2016) e Lia Schucman (2014), entre outros. 
processos de alienação se torna objeto em um sistema de supremacia branca. (PIRES, 2017, p. 8)

Retomo algumas das teses de Gayatri Spivak, em seu célebre ensaio "Pode o subalterno falar?", que são importantes para o que se discute aqui. A primeira delas é a de que o pensamento ocidental é formulado em suporte aos interesses econômicos ocidentais. Para ela, retomando noções pós-estruturalistas sobre a formação da subjetividade, o conhecimento não é nunca inocente e reflete sempre o interesse (explícito ou não, consciente ou não) de seus autores (SPIVAK, 2010, p. 20-40). Uma segunda tese é a de que, como intelectuais (e como militantes), não somos capazes de representar a voz dos oprimidos como se fôssemos um meio transparente, como se não mediássemos essa voz, porque somos todos intelectuais, militantes e oprimidos - formados nas relações de poder. A própria relação entre representantes e representados já nos atravessa subjetivamente e nos (re)constitui, de modo que não existe um representante soberano e transparente, capaz de representar um "outro" constituído de maneira definitiva e pronto a ser apresentado (SPIVAK, 2010, p. 45). ${ }^{11}$ Por fim, com relação à tese conhecida e controversa de Spivak de que o subalterno não pode falar, a autora lembra que qualquer ato de fala pressupõe uma interação entre falante e ouvinte. Nesse sentido, ela famosamente sustenta que o subalterno não pode falar, não porque não o saiba fazer, mas porque não há escuta dentro da ordem hegemônica: "quando se diz "não pode falar', isso significa que, se consideramos que falar pressupõe fala e escuta, essa possibilidade de resposta, de responsabilidade, não existe na esfera do subalterno" (SPIVAK, 1992, p. 46). A posição do "outro" subalternizado, sua experiência da opressão e silenciamento, só pode ser ouvida se articulada em relação a um vocabulário hegemônico, que não foi feito para acomodar seus interesses. Ao subalterno é negada a condição de sujeito de sua própria luta, em condições que não sejam as hegemônicas. Nesse sentido, resta a ele essa posição de "objeto" sobre o qual se fala. A subalternidade, para Spivak, se produz justamente nessa impossibilidade de protagonismo do sujeito subalternizado e de articulação de sua própria luta em seus próprios termos. A gramática disponível, e as instituições que dela emergem, são inexoravelmente constituídas nas relações de poder que privilegiam saberes e corpos europeus. Falta ao subalterno agência política, ou seja, "uma forma de ação validada institucionalmente". Daí a impossibilidade de articular um discurso de resistência que esteja fora dos discursos hegemônicos" (ALMEIDA, 2010, p. 15).

11 Spivak formula esse ponto em crítica ao trabalho de Foucault e Deleuze, que, ao falarem da opressão capitalista, deixaram de fora a divisão internacional (colonial) do trabalho e pressupuseram ser possível falar da "classe trabalhadora", como se essa subjetividade (trabalhadores) existisse "soberanamente", na condição de uma categoria monolítica e indiferenciada, e como se eles fossem transparentes ao representá-la. 
Partindo de premissas similares, uma das principais reivindicações do pensamento decolonial é a de que precisamos descolonizar o saber: o pensamento hegemônico impôs, de maneira violenta, ao mundo periférico e subalternizado categorias de apreensão da realidade que desorganizaram outras formas de estar no mundo e criaram hierarquias sociais rígidas (LUGONES, 2014). Tais "violências epistêmicas” (FOUCAULT apud SPIVAK, 2010, p. 45-70) criaram classes de saber, extinguindo total ou parcialmente cosmovisões originais e classes de sujeitos, impondo aos mais subalternos o ônus de "reapreender" o mundo a partir da gramática do colonizador. ${ }^{12}$ Violências epistêmicas têm consequências profundas, tanto em termos de relações de poder hierárquicas quanto em termos da autoestima dos sujeitos subalternizados, que têm na "raça” seus limites e suas medidas. Assim, em outras palavras, uma das tarefas autoimpostas do pensamento decolonial é a problematização de categorias epistemológicas a partir da raça.

Maria Lugones, no artigo "Rumo a um feminismo descolonial" (2014, p. 936), afirma que "imposição colonial do gênero atravessa questões sobre ecologia, economia, governo, relaciona-se ao mundo espiritual e ao conhecimento". Segundo ela, a própria empreitada colonial foi levada a cabo através das categorias sexo e gênero e pode ser traduzida no projeto "civilizatório" europeu de transformar as "bestas", racialmente marcadas, encontradas aqui nas Américas, em não homens e não mulheres. De fato, a dicotomia central da modernidade, na visão de Lugones, é humano e não humano, e essa dicotomia se realiza a partir da atribuição de gêneros aos humanos. Apenas os colonizadores tinham gênero e eram homens e mulheres, com todas as hierarquias conhecidas nessa dicotomia. Aos colonizados, negava-se um gênero e atribuía-se o sexo macho ou fêmea, em uma operação epistêmica que permitiu o que poderia ser chamado de "feminização do sujeito colonizado". Em outras palavras, o "acesso brutal aos corpos das pessoas através de uma exploração inimaginável, violação sexual, controle da reprodução e terror sistemático” (LUGONES, 2014, p. 938).

A imposição do sistema sexo-gênero foi uma das ferramentas de destruição de cosmovisões que não se organizavam, necessariamente, por meio do sexo e gênero. A imposição dessas categorias como critério politicamente determinante de organização social é, assim, uma forma de violência epistêmica com profundas consequências políticas e sociais que permanecem na atualidade. A análise de Lugones mostra como o elemento raça é fundamental para a compreensão da extensão em que um sujeito poderia ou não ter um gênero, em que medida certas fêmeas, marcadas racialmente, são "mulheres" ou não. Diversas teóricas do feminismo negro há muito tempo denunciam a impossibilidade de homens e mulheres negras se

12 Sobre violência epistêmica, o texto "Pode falar o subalterno?", de Gayatri Spivak (2010), é referência. Spivak é uma das figuras proeminentes do pensamento pós-colonial e dos estudos subalternos, que tem denúncias e reivindicações próximas, ainda que não idênticas, ao pensamento decolonial. 
encaixarem nos modelos de masculinidade e feminilidade criados a partir da experiência branca europeia, e sua permanência nos lugares dos "não homens" e "não mulheres".

Assim, os estereótipos de gênero classicamente identificados pelo feminismo hegemônico para ilustrar as formas de naturalização da opressão contra mulheres não se aplicam da mesma maneira sobre os corpos das "não mulheres". O mito da fragilidade feminina, a exigência de castidade da mulher e a divisão sexual do trabalho que confinava a mulher à esfera privada, por exemplo, não operam igualmente sobre corpos brancos e negros. Sueli Carneiro (2003) já denunciava que mulheres negras sempre trabalharam nas "lavouras ou nas ruas, como vendedoras, quituteiras ou prostitutas". Seus corpos, marcados simultaneamente pelo sexismo, pelo racismo e também pelo classismo, adquirem uma inteligibilidade social específica, que se materializa no Brasil contemporâneo nas figuras da mulata e da empregada doméstica, como ensina Lélia Gonzalez (1984, p. 228). ${ }^{13}$ Da mesma maneira, a discussão do contrato sexual do trabalho, que coloca o homem como provedor e a mulher como cuidadora, bem como a luta pelo acesso das mulheres ao mercado de trabalho, assumem contornos muito distintos no caso de mulheres negras:

[...] nós [mulheres negras] fazemos parte de um contingente de mulheres, provavelmente majoritário, que [...] não entenderam nada quando as feministas disseram que as mulheres deveriam ganhar as ruas e trabalhar! (CARNEIRO, 2003)

Voltando ao tema da violência contra as mulheres, Bruna Jaquetto Pereira e Tania Mara Campos Almeida (2012) sintetizam o modo como representações específicas do corpo da mulher negra funcionam para autorizar as agressões no âmbito doméstico:

São representações que orientam posturas e práticas violentas contra as mulheres pretas e pardas por parte dos seus companheiros, e que abrangem: constante fiscalização da sua sexualidade, na medida em que são consideradas hipersexualizadas; a negação da sua sexualidade, uma vez que os seus atributos estéticos estão distantes daqueles atribuídos às mulheres brancas, tomados como padrão de beleza; a violência sexual, como forma de humilhação e/ ou pela desconsideração de sua humanidade; as humilhações degradantes, com ou sem a presença do insulto racial, ancoradas na percepção do seu status socialmente subalterno; a exploração econômica dos recursos obtidos pelo seu trabalho remunerado, com base na imagem de que são trabalhadoras incansáveis e que o mero fato de relacionar-se com elas constitui, por si só, um favor que deve ser retribuído; a exploração do seu trabalho

13 Um exemplo clássico da crítica ao mito da fragilidade feminina é o livro The feminine mystique, de Betty Friedan (1963). 
no âmbito doméstico, com base na imagem de que são naturalmente cuidadoras; a agressão física brutal, que parte do pressuposto de sua força física avantajada. (ALMEIDA e PEREIRA, 2012, p. 58-59)

As teorias da interseccionalidade também anunciam as muitas maneiras de "ser mulher" e de "ser uma pessoa negra" (CRENSHAW, 1991, p. 1241). O termo "interseccionalidade" designa uma ferramenta analítica que permite compreender e dar visibilidade ao modo como diferentes aspectos das identidades políticas de indivíduos, como gênero, raça, sexualidade e classe, podem se combinar para criarem formas de opressão que agem de maneira específica sobre esses corpos. Segundo Carla Akotirene (2018, p. 14), “a interseccionalidade visa dar intrumentalidade teórico-metodológica à inseparabilidade instrumental do racismo, capitalismo e a cis-heteropatriarcalidade". Corpos marcados sexual e racialmente, por exemplo, experimentam de modo singular e simultâneo o racismo e o sexismo das sociedades contemporâneas. Padrões culturais de opressão não são apenas inter-relacionados, mas também são, de fato, reciprocamente constituídos (COLLINS e BILGE, 2016). ${ }^{14}$

14 O termo "interseccionalidade" foi cunhado por Kimberlé Crenshaw no artigo "Demarginalizing the intersection of race and sex: a black feminist critique of antidiscrimination doctrine, feminist theory, and antiracist politics" (University of Chicago Legal Forum, v. 14, p. 538-554, 1989), publicado em 1989, e ganhou notoriedade em 1991 com o artigo "Mapping the margins". Contudo, como sustenta Patricia Hill Collins, "interseccionalidade" passou a ser o termo usado para nomear um tipo de reflexão sobre justiça social que sempre esteve presente na obra de diversas feministas negras. Collins (2016) afirma que o termo, por exemplo, substituiu o que ela própria designava como "Black feminist thought”. Angela Davis e Bell Hooks, antes disso, já haviam discutido o tema das relações entre gênero e raça, destacando as sobreposições. Cf. DAVIS, Angela. Women, race and class. New York: Ramdom House, 1981; HOOKS, Bell. Ain't I a women: black women and feminism. Boston: South End Press, 1981. É oportuno lembrar que o título de Hooks celebra o discurso de Sojourner Truth, ex-escrava e militante abolicionista americana, na Women's Convention em Akron, Ohio, em 1851. No Brasil, Lélia é definitivamente a precursora e ainda a maior expoente da discussão. Seu conceito de "Amefricanidade", para falar de mulheres negras e indígenas nas Américas, já em 1988, relaciona-se com o que suas contemporâneas faziam nos Estados Unidos e antecipa muitas das discussões do feminismo descolonial. Cf. GONZALEZ, Lélia. Por um feminismo afro-latino-americano. Isis Internacional/Mudar, Santiago, n. 9, 1988. Contudo, Collins e Bilge (2016) sustentam que, ao mesmo tempo que o termo "interseccionalidade" permitiu que a discussão sobre as formas como racismo e sexismo estão imbricados para criar injustiças sociais, própria de movimentos sociais de base, "viajasse" até a academia, ele também possibilitou uma gradativa perda de tração crítica do termo como indicativo de uma práxis social de crítica das bases materiais da injustiça, transformando-se em uma categoria meramente "analítica" que, inclusive, passa a ser acusada de "embranquecimento". Akotirene (2018, p. 19), de modo contundente, reitera esse ponto: "A serventia contemporânea promove carreiras acadêmicas da Europa e branquitudes brasileiras, já acostumadas com a apropriação intelectual indevida [...]. É da mulher negra o coração do conceito de interseccionalidade". 
Assim, quando fala em nome da mulher, como categoria universal e uniforme, o feminismo corre o risco de ensejar formas de dominação intragrupo, em que mulheres de raças e classes dominantes reproduzem contra mulheres subalternizadas formas de dominação semelhantes às que denunciam no patriarcado. Por exemplo, o reconhecimento do fato de a violência doméstica não ser um problema exclusivo de comunidades marcadas racial e etnicamente, diz ela, foi transformado na afirmação de que ela afeta todas as mulheres igualmente, o que não é verdade. Algumas mulheres enfrentam desafios desproporcionais para superar o problema, e a falta de reconhecimento dessa circunstância acarreta o silenciamento de mulheres subalternizadas. Nas dinâmicas em torno da LMP, a mulher negra vítima de violência foi subalternizada: aparece como o símbolo da vítima de violência doméstica, mas depois deixa de ser ouvida como agente de sua própria luta de emancipação. Veremos a seguir.

\section{A PRODUÇÃo DA SUBALTERNIDADE DA MULHER NEGRA NA MILITÂNCIA CONTRA A VIOLÊNCIA DOMÉSTICA}

De acordo com Kimberlé Crenshaw (2002, p. 5-6), os processos de subalternização dos corpos que experimentam formas interseccionais de violência e silenciamento ocorrem por meio de operações de superinclusão ou de subinclusão. As primeiras se manifestam quando um problema que afeta exclusiva ou desproporcionalmente um subgrupo de mulheres é "absorvido pela estrutura de gênero, sem qualquer tentativa de reconhecer o papel que o racismo ou alguma outra forma de discriminação possa ter exercido em tal circunstância”. Como consequência, as especificidades do problema deixam de ser consideradas e as políticas públicas voltadas para a questão não são eficientes como deveriam. As operações de subinclusão, a seu turno, referem-se a situações em que um problema afeta um subgrupo de mulheres, mas "não é percebido como um problema de gênero, porque não faz parte da experiência das mulheres dos grupos dominantes" (CRENSHAW, 2002, p. 5).

Entendo que, na luta contra a violência de gênero no Brasil, ocorreram as duas formas de invisibilização das mulheres negras, bem como de outras mulheres não brancas. Houve sobreinclusão na medida em que as especificidades do problema da violência doméstica contra mulheres negras não foram adequadamente contempladas pelas escolhas que resultaram na lei. Refiro-me especificamente à sobrevalorização das ações do Judiciário no momento de formulação da lei ${ }^{15}$ e ao posicionamento da militância que, mesmo afirmando a importância

15 Quem chamou a atenção para os problemas na priorização do Judiciário na luta contra a violência doméstica no Brasil foi Marilia Montenegro. Agradeço a ela por esse ponto, que, por ora, prefiro desenvolver a partir da crítica ao Judiciário vinda de autores associados à Crítica Racial da Criminologia, em vez da 
da prevenção, investiu na persecução criminal como símbolo contra a banalização do crime de violência doméstica (FLAUZINA, 2015, p. 132). Houve, ainda, subinclusão das mulheres negras na luta contra a violência sobre corpos femininos, porque, se o objetivo do feminismo é emancipar todas, precisaríamos ter incorporado a violência racial na pauta feminista relativa à violência de gênero, e mesmo a contextos que escapam à violência doméstica, mas que vitimam milhares de mulheres negras.

Em artigo seminal sobre o conceito de interseccionalidade, Kimberlé Crenshaw (1991, p. 1259) demonstra com dados e situações empíricas que os esforços feministas para construir a violência doméstica como um problema de todas as mulheres, de todas as raças e camadas sociais, acabaram por operar uma superinclusão, realocando verbas para políticas públicas, como assistência jurídica, que todavia não atendiam às necessidades mais prementes de mulheres negras. Crenshaw (1991, p. 1245-1246, 1251) destaca, por exemplo, que a maioria das mulheres que procuram abrigos, por exemplo, está desempregada ou subempregada, enfrentando a dificuldade financeira como questão primeira para romper o ciclo de violências. A rede privada de apoio a essas mulheres também tende a ser mais precária: como o desemprego é maior entre a população negra, as mulheres negras teriam menor probabilidade de conseguir suporte financeiro de amigos e familiares do que as brancas. Para sair da situação de violência, elas precisam de políticas públicas de redistribuição, como abrigos dignos, programas de capacitação e colocação profissional e creches para seus filhos.

Em grande medida, os mesmos pontos podem ser destacados em relação à LMP. Tanto na prevenção quanto na repressão, atribuiu-se protagonismo ao Judiciário em detrimento dos demais poderes. E, na implementação da lei, percebemos que o Judiciário dá prioridade às ações de repressão, em especial às de natureza penal. Ocorre que pesquisas diversas sobre racismo, sobre acesso à Justiça e sobre violência revelam que a população negra e pobre, e as mulheres dentro desses grupos em especial, tem dificuldades e resistências enormes em buscar no Judiciário soluções para seus problemas. De fato, dois artigos da lei dispõem sobre a rede de atendimento a essas mulheres, envolvendo as administrações municipal, estadual e federal. Contudo, os serviços decorrentes desses artigos nunca foram suficientemente implantados e agora vêm sendo desmontados com rapidez, sem que o movimento feminista hegemônico se insurja de maneira significativa.

Criminologia Crítica. De acordo com essa perspectiva, o estado de Direito e o Judiciário são produtos de esquemas que nunca tiveram como objetivo a emancipação e a igualdade de todos os sujeitos, mas sim a subordinação de certos corpos (não brancos e colonizados) para benefício e privilégio de outros corpos (brancos e colonizadores). Por isso, o Judiciário não foi "feito" para proteger mulheres negras e, assim, de fato, não as protege. Sob essa perspectiva, ver: FLAUZINA, Ana et al. Discursos negros: legislação penal, política criminal e racismo. Brasília: Brado Negro, 2015. 
De acordo com pesquisa do Geledés - Instituto da Mulher Negra, com sete centros de atendimento às mulheres da cidade de São Paulo, padrões recorrentes encontrados nos atendimentos às vítimas de violência referem-se à resistência a registrar o boletim de ocorrência contra o agressor, em razão de diversos motivos: atendimento hostil nas delegacias, falta de informação quanto às suas possibilidades jurídicas, confusão de emoções com relação ao agressor e pai de seus filhos, medo de que eles percam o emprego ou de que revidem, entre outros. Também são recorrentes relatos de atendimento ruim nas delegacias e de uma enorme dificuldade de sair de perto do agressor por falta de lugar seguro para onde ir. A maior parte dessas mulheres não tem renda suficiente para arcar com moradia e alimentação própria e de seus filhos e não conta com uma rede privada que possa apoiá-la. Assim, programas de abrigamento, de pós-abrigamento e programas de moradia (aluguel social ou habitação própria) parecem ser absolutamente vitais para essas mulheres superarem a situação emergencial de violência e retomarem suas vidas fora do alcance do agressor. Sobre as deficiências da política de abrigamento, uma das profissionais entrevistadas informa:

A rede socioassistencial é totalmente falha [...], seria necessário que essa mulher tivesse uma estrutura para sair desse processo. E aí ela está ali no abrigo com outras mulheres, com outras crianças, muitas delas também têm filhos, os conflitos são constantes... E aí ela começa a olhar para aquela situação inicial quando ela chegou aqui, antes de ir para o abrigo, e ela começar a pensar: "Não estava tão ruim assim. Vou voltar. Por que vou ficar aqui? Fazendo o quê?". Então muitas voltam para o companheiro, as que não voltam para o companheiro têm uma dificuldade tremenda de seguir, porque não conseguem trabalho, porque não conseguem alguém para cuidar dos seus filhos. (CARNEIRO, 2017, p. 134)

As vítimas entrevistadas nessa pesquisa relatam ter recebido um atendimento muito mais adequado nos centros que compõem a rede do que nas delegacias, nas defensorias e nos juizados. Sentem-se mais acolhidas, respeitadas e orientadas. Contudo, as profissionais (assistentes sociais, psicólogas, advogadas e outras) desses mesmos centros - muitas delas negras - contam sua frustração com a burocracia e a inoperância dos serviços, e também com a falta de interesse dos movimentos sociais com relação a esse ponto:

E tem coisas que eu acho que cai na conta dos movimentos de mulheres e nos movimentos feministas, coletivos e afins. Porque isso que a gente está passando aqui é público, o sucateamento do serviço da rede é público. E, quando a gente tentou ir para o enfrentamento via Defensoria Pública, escrevemos carta, fizemos manifestação, das trabalhadoras dos Centros de Defesa, somente dois coletivos chegaram junto, e o resto... [...], mas a gente sentiu uma solidão profunda: cadê os movimentos de mulheres que tanto lutaram para que esses serviços existissem? Porque a gente sabe que esse serviço é fruto da luta desses movimentos... onde eles estão? (CARNEIRO, 2017, p. 151) 
Ana Flauzina (2015, p. 116) levanta mais um problema de silenciamento a partir das dinâmicas entre o que ela chama de "resistência", formada por mulheres que se irmanam "como sobreviventes do quotidiano", e de "militância", que seria a "rebeldia politizada". Flauzina entende que, em momentos importantes, escolhas da militância resultaram em processos de silenciamento da resistência - em sua maioria, mulheres negras e pobres. Há, segundo ela, uma sobreposição de silêncios, prática que a LMP não foi capaz de resolver. Vítimas de violência, via de regra, querem fazer cessar a violência (e não querem necessariamente o encarceramento do agressor) e querem ser respeitadas como sujeitos. Com a autoestima dilacerada na dinâmica de violência, essas mulheres têm muita dificuldade de buscar ajuda; contudo, quando finalmente o fazem, são engolidas e mais uma vez silenciadas pela engrenagem estatal. ${ }^{16}$ Essas mulheres, a "resistência", querem os serviços da LMP, como o abrigamento e o aluguel social, querem as medidas protetivas, mas só podem pleitear tais prestações se registrarem o boletim de ocorrência. Muitas não seguem diante desse obstáculo. Sem o boletim de ocorrência, a maior parte das proteções previstas na LMP não pode ser deferida na maioria das jurisdições. Ainda que a criminalização do agressor possa ter um papel importante no enfrentamento à violência, ela não pode ser a principal resposta do Estado nem condicionar as demais. ${ }^{17}$

Para Flauzina (2015), a desnaturalização da violência doméstica e a desimunização do agressor às consequências jurídicas desse crime foram conquistas importantes da militância feminista, desafiando um discurso ainda poderoso de banalização da violência contra a mulher, obtidas a partir da mobilização do direito penal. No entanto, segue a autora, há um investimento muito maior da militância na derrubada dos obstáculos à persecução criminal do agressor do que na valorização da vontade da vítima. Seu grande exemplo é a restrição à possibilidade de retratação da vítima. A justificativa para essa restrição é a dificuldade de se falar de autonomia da vítima em contextos de opressão sistemática. Quis-se resguardar a vítima da pressão para que retratasse. No entanto, a opção da militância não foi lutar por melhores condições para manifestação da retratação, com adequada assistência jurídica e emocional, além de condições materiais para exercer essa opção de modo autônomo. Nesse sentido, para Flauzina, a vítima foi instrumentalizada. Seu grito de denúncia vale para inaugurar o processo, mas a partir daí sua voz não é mais considerada autônoma. Ecoando Flauzina, Akotirene (2018, p. 64) afirma:

16 Citando dados de pesquisa do Ipea de 2012, a autora entende que mulheres vítimas de violência doméstica demandam escuta de sua experiência, respeito por sua dor e a cessação da violência. Não buscam o encarceramento do agressor. Com efeito, a luta da militância pela vedação da possibilidade de retratação da vítima nos crimes de lesão corporal leve e da possibilidade de suspensão condicional do processo, para ela, foram escolhas problemáticas justamente porque vão de encontro a essas demandas (FLAUZINA, 2015, p. 129).

17 A esse respeito, ver, também, Carneiro (2017, p. 136 e 149). 
[...] o fato de mulheres negras quererem mediar o fim da violência sem, necessariamente, demandarem a prisão dos seus companheiros, levando em conta a marca colonial conter a privação de liberdade. Dizer isto não significa defender o pagamento de cesta básica à pena punição alternativa por danos físicos, patrimoniais, psicológicos e morais contra a mulher, mas reafirmar a necessidade de identificar o elitismo e racismos da Lei Maria da Penha e seus a priori raciais infantilizados da mulher negra, querendo ela dar e retirar a quina sem a presença do juiz.

Há, por fim, outra forma de subinclusão, relativa ao enquadramento da luta para combater a violência contra a mulher na pauta do feminismo hegemônico, que desconsidera contextos de violência a que mulheres negras estão muito mais expostas do que as brancas. A pauta da luta contra a violência de gênero centrou-se nos aspectos relativos à violência doméstica e sistematicamente excluiu as questões relativas à chamada "violência comum". No entanto, um contingente expressivo de mulheres assassinadas e agredidas refere-se a contextos de violência diferentes do doméstico. Com efeito, o Mapa também nos mostrou que 62,7\% das vítimas de violência atendidas no Sistema Único de Saúde (SUS) foram agredidas por familiares e parceiros, indicando ocorrência de violência doméstica, enquanto os demais 37,3\% provavelmente se referem a mulheres mortas pela chamada "violência comum". Sabemos que as mulheres negras estão mais expostas a condições de precariedade agudas, politicamente induzidas, o que aumenta a exposição à violência do tráfico e à repressão policial. Arriscam-se mais do que as brancas para esclarecer as circunstâncias da execução sumária de seus parceiros e filhos. Esses contextos marcam de maneira violenta seus corpos e suas vidas. O caráter racial da violência de estado é conhecido, mas o caráter de gênero é menos discutido, talvez porque afete principalmente as negras. Os mesmos códigos de gênero que estruturam o sexismo, relativos à masculinidade, somados aos códigos de branquitude, resultam no quadro atual de violência de estado contra corpos negros. Mas o tema dificilmente entra nas pautas do feminismo hegemônico porque é percebido como um problema que afeta homens (pobres e negros). Há décadas os feminismos negros alertam para essa forma de silenciamento, instando as feministas a assumirem o racismo em suas pautas:

Racismo não é uma questão apenas porque ativistas feministas brancas sejam individualmente racistas. Elas representam uma pequena percentagem das mulheres nesta sociedade. Elas poderiam ser todas antirracistas desde o início, e continuaria sendo necessário incluir a eliminação do racismo com uma questão feminista central. (HOOKS, 1984, p. 51)

Com efeito, as insuficiências da resposta estatal para o problema da violência doméstica, por um lado, apontam para a necessidade de avançarmos na luta por políticas públicas que funcionem melhor. Por outro lado, retornando a insights decoloniais, essas insuficiências 
apontam também para o próprio modus operandi de uma institucionalidade montada sobre uma lógica de expropriação de uns, e de concessão de privilégio para outros: "Um Estado que tem herança de massacre contra os indígenas, de escravização, e isso não vai ser superado pelo Estado, vai ser superado pelas lutas. E aí será que a vida das mulheres pobres e negras cabe nos Tribunais Penais? Cabe no Estado?” (CARNEIRO, 2017, p. 183).

Uma das profissionais de um dos centros da rede de atendimento de São Paulo entrevistadas pela Geledés traduz perfeitamente essa ideia, afirmando a necessidade de pensarmos em estratégias de luta e mobilização que não sejam reféns de um Estado que se estruturou sobre bases racistas e sexistas, e que segue servindo a essas lógicas. A partir desse alerta, a tarefa principal passa a ser a priorização dos espaços e das modalidades de auto-organização dos sujeitos subalternizados: ${ }^{18}$

Olhar para isso não significa ser a favor de menos direito, de desmantelar mais, disso aqui acabar, mas é problematizar isso no movimento o tempo inteiro, contraditório assim, dialético mesmo. [...] Eu acho que o espaço [CDCM] pode possibilitar é justamente a organização autônoma. Retomar processos organizativos, que sempre existiram aqui, que estão nas heranças africanas, indígenas. (CARNEIRO, 2017, p. 184)

\section{A PROdUÇÃo da SUbalternidade da MULHER NEGRA NA IMPLEMENTAÇÃo DA LMP}

A LMP faz uma grande aposta na via judicial de enfrentamento à violência doméstica, como afirmado. Contudo, recorrendo novamente à terminologia de Crenshaw, é possível verificar que ocorreram, ao longo do processo de implementação da lei pelo sistema de Justiça, formas distintas de sobreinclusão das mulheres negras na aplicação da lei, invisibilizando

18 Pedro Rennó Marinho, examinando o caráter performático do direito à moradia, acaba revelando uma conexão interessante entre violência de gênero e direito à moradia, a partir de um exemplo de auto-organização potente de mulheres vítimas de violência que se utilizaram criativamente de políticas sociais do Estado. Refere-se à história do Residencial Orquidea, em Manaus, formado por iniciativa de mulheres negras e indígenas pobres, vítimas de violência doméstica, que perceberam a dificuldade que a falta de moradia impunha a mulheres que saíam de relacionamentos abusivos, seja porque perdiam ou porque vendiam a casa onde antes moravam com o agressor e não tinham a capacidade de conseguir ou comprar uma casa nova com as verbas de que dispunham após o término da relação. Essas mulheres formaram aos poucos uma rede para abrigar as vítimas e seus filhos provisoriamente. Mais tarde, articularam-se para conseguir financiamento público por meio de uma das modalidades do programa "Minha casa, minha vida" e construíram, elas próprias, o residencial, conferindo o título de propriedade do imóvel exclusivamente a mulheres (MARINHO, 2019). Histórias como essa podem nos ensinar muito sobre estratégias eficientes de livrar mulheres de situações de violência doméstica. 
aspectos importantes de sua experiência de situação de violência doméstica. Parece claro, a partir das considerações feitas, que esse resultado não é acidental. A via judicial constitutivamente não foi feita para acomodar de modo natural as demandas de corpos historicamente subalternizados.

A pesquisa de Bernardes e Albuquerque (2016), a partir da leitura das narrativas contidas nos 187 procedimentos de MPU no Rio de Janeiro, em que as vítimas eram mulheres negras e de baixa renda, permitiu identificar que o Estado ignorou aspectos econômicos e materiais essenciais da situação de violência a que essas mulheres estão submetidas, tanto no momento da capitulação do crime quanto no momento da solicitação (pela autoridade policial, em nome da vítima) e da concessão da medida protetiva (BERNARDES e ALBUQUERQUE, 2016). ${ }^{19}$ A captura do mecanismo das MPUs pela lógica penal tem consequências graves, podendo levar à inefetividade da proteção. Como ilustração dessa dupla forma de invisibilização da precariedade desproporcional a que essas mulheres estão expostas (na configuração do crime e na concessão das MPUs), menciono o caso de Claudia (nome fictício), que, ao pedir dinheiro ao companheiro e pai de suas filhas, começa a ser agredida por ele na rua:

[...] embora o gatilho da agressão esteja ligado à subsistência familiar, não foi deferida (aliás, nem demandada) a medida [...] dos alimentos provisionais. Conquanto a integridade física de Claudia esteja protegida formalmente [pelo deferimento da MPU de afastamento], sua exposição à violência, em decorrência da necessidade de contato para alimentação sua e da filha, segue idêntica. A capitulação dos fatos a partir da figura da lesão corporal (art. 129 CP) obscurece o aspecto patrimonial da violência, de forma que a resposta jurídica (afastamento do agressor) parece, na melhor das hipóteses, inócua para fazer cessar a violência. (BERNARDES e ALBUQUERQUE, 2016, p. 718)

Mulheres negras também foram subalternizadas nos processos judiciais na medida em que experiências sofridas de violência psicológica não são reconhecidas como tal. Ofensas racistas não são enquadradas como forma de violência psicológica no contexto da LMP tanto para a configuração do crime quanto para outros serviços no âmbito dos juizados, como os

19 Como exemplo, Nadir (nome fictício), depois de anos sofrendo violência doméstica, separou-se de seu marido, que passou, então, a invadir sua casa e a subtrair seus bens, como a geladeira e o fogão, para vendê-los. O modo como o Estado transformou esse contexto em informações juridicamente relevantes é surpreendente: “[...] a capitulação utilizada foi a de Exercício Arbitrário das Próprias Razões (art. 354 CP), tipo penal que exige uma pretensão legítima a ser cobrada, no caso narrado, pretensão de índole financeira. Não foi aventada nos autos, contudo, qualquer dívida da vítima para com o agressor" (BERNARDES e ALBUQUERQUE, 2016, p. 731). 
grupos de reflexão dos agressores (FLAUZINA, 2015, p. 138). Na pesquisa de Bernardes, Costa e Vidal com 355 autos de MPU no Rio de Janeiro, não foram encontrados em nenhum dos autos analisados relatos de xingamentos e/ou de outras formas de violência baseados na raça. Podemos aventar que essa ausência seja motivada tanto pela dificuldade de a própria vítima enquadrar a violência racial que sofreu nesse conceito quanto pelo modo como elas são atendidas pelas autoridades policiais, que direcionam os depoimentos a partir daquilo que julgam relevante no contexto da violência doméstica. Ambas as situações são manifestações de um racismo estrutural profundo.

Bruna Cristina Jaquetto Pereira (2016, p. 90) investigou como o racismo dá forma à experiência das mulheres entrevistadas, todas elas negras e vítimas de violência doméstica, em três sentidos: (a) experiências anteriores de violência, em seus círculos familiares próximos, que estruturam o universo interpretativo da vivência de violência doméstica atual que as entrevistadas denunciam; (b) os contextos de violência psicológica/moral relatada por elas; e (c) a forma de reação às agressões sofridas. Segundo Pereira (2016), há uma série de expectativas com relação ao comportamento dessas mulheres marcadas racialmente, mas, "ao considerar apenas a condição de gênero, fica difícil compreender quais são as origens e sentidos de tais expectativas, que parecem destoar das representações tidas por tradicionais”. Essas formas de violência têm sido invisíveis ao sistema de Justiça criado pela LMP, apesar do sofrimento que causam.

Por fim, um padrão que chamou a atenção na pesquisa de Bernardes, Costa e Oliveira (2016), já mencionada, foi o de que um grande obstáculo à efetivação das MPUs tem sido o cumprimento do mandado de intimação. De acordo com os resultados da pesquisa, de modo muito consistente, os três juizados analisados cumpriam o prazo de 48 horas para deferimento e expedição das medidas, previsto no art. 18 da lei, mas muitos mandados não eram cumpridos ou havia um lapso temporal considerável entre a expedição e o cumprimento (BERNARDES, COSTA e OLIVEIRA, 2016, p. 134). Em geral, a justificativa, sempre curta, para esse lapso ou para o não cumprimento era a não localização do réu ou do endereço informado. O Estado, sabidamente, não acessa comunidades carentes, a não ser por meio de incursões policiais, e a dificuldade de cumprimento dos mandados pode ser vista como mais uma expressão da iníqua distribuição da precariedade e da exposição à violência. ${ }^{20}$

20 A pesquisa de Marilia Montenegro (2015, p. 171-172) também identifica aspectos específicos da violência doméstica contra mulheres de baixa renda. A partir de pesquisa empírica na cidade de Recife, inicialmente em juizado especial criminal, e depois da aprovação da LMP em juizado de violência doméstica, ela destaca o recorte de classe no recurso a instâncias judiciais e ressalta que muitos problemas cíveis chegavam a esses juizados, na medida em que o acesso à Justiça de natureza civil e, em especial, de família é dificultado às classes mais baixas: altos custos, necessidade de advogado, defensorias públicas insuficientes ou inexistentes, ritos formais e lentos. Assim, problemas relacionados a términos de relacionamento, como dividir bens, determinar custeio das necessidades dos filhos, etc., chegam ao Judiciário por meio das delegacias, 
Os problemas na aplicação da LMP levantados apontam para dificuldades epistêmicas, políticas e jurídicas que nos permitem suscitar questões acerca da capacidade do sistema de Justiça de proteger sujeitos subalternizados. Há problemas graves de enquadramento: o que conta como juridicamente relevante e o que é deixado de fora? O que pode ser considerado violação de direitos e o que não pode? Há problemas igualmente críticos sobre a linguagem utilizada pelo direito, que estruturalmente exclui certos corpos das proteções estatais: qual a intensidade da proteção à mulher que sofre danos econômicos? Quem goza de credibilidade diante do sistema e não precisa arcar com ônus probatório? Por fim, a experiência de quais corpos foi considerada na elaboração das respostas de um Estado que, por exemplo, tem dificuldade de acessar territórios de populações pobres para cumprir um mandado?

\section{CAminhos para a luta contra a violênCia de GÊNERO}

Neste artigo, refletiu-se sobre questões epistemológicas relativas à produção da subalternidade da mulher negra vítima de violência, negando-se a ela a condição de sujeito da própria emancipação. Foi articulada essa discussão, a princípio, com a necessidade de descolonização do saber e das categorias a partir das quais são autorizadas certas falas e desqualificadas outras, para enfim discutir o "gênero" como categoria que pode servir a interesses hegemônicos se não for devidamente racializada e contextualizada. Foi sustentado que políticas públicas centradas em um conceito universal de "mulher”, como a LMP, não dão conta dos problemas reais de mulheres negras vítimas de violência. A priorização do processo judicial de responsabilização do agressor, em detrimento de políticas públicas de assistência social integral às vítimas, a insuficiência de políticas de empoderamento das vítimas, o descompasso entre a realidade dos episódios de violência e aquilo que é enquadrado como juridicamente relevante e a própria definição do que é violência de gênero (excluindo a violência gerada pela guerra às drogas) são exemplos das formas nas quais a política brasileira contra a violência de gênero continua mantendo vítimas de violência em uma condição de subalternidade.

A advertência de Spivak aos intelectuais que pretendem falar por outros oprimidos nos ajuda aqui a entender também os dilemas entre a militância e a resistência subalterna. Em

no caso das famílias pobres, e não das varas de família. A informalidade da vida nas periferias urbanas também não é alcançável pelo direito de família: imóveis não registrados e empregos sem carteira assinada, por exemplo, não permitem as partilhas de bens e a determinação de pensão alimentícia. É importante destacar que Montenegro, valendo-se do marco teórico da criminologia crítica, que, por ora, descarto, chega a conclusões menos otimistas do que as aqui depreendidas quanto às possibilidades emancipadoras da LMP. 
um mundo marcado por operações de violência epistêmica, nenhum discurso de resistência pode ser articulado fora do discurso hegemônico. Se não for alterada de maneira radical essa ordem de coisas, a intelectual e a militante estarão fadadas a constituir reiteradamente a vítima de violência como um objeto de conhecimento, e não como agente de sua própria emancipação, e a reproduzir as estruturas de poder e a opressão contra as quais se insurgem. A tarefa que se impõe, então, é a de trabalhar para alterar as condições de produção da subalternidade em um nível epistêmico, e, em um nível político, alterar a iníqua infraestrutura indutora e distribuidora da precariedade dos corpos. Segundo Spivak (1992, p. 45, grifo no original), "não se dá voz ao subalterno. Trabalha-se para o subalterno; trabalha-se contra a subalternidade". Tal tarefa pressupõe como ponto de partida o desenvolvimento do que poderíamos chamar de uma "infraestrutura de escuta", sem a qual a voz da vítima de violência é silenciada diante dos megafones dos poderosos (FLAUZINA, 2015). Lutar contra as estruturas produtoras da subalternidade parece significar, acima de tudo, construir essa infraestrutura de escuta que alcance a fala do subalterno.

Entende-se que a LMP pode ser um marco normativo sobre o qual se apoiem infraestruturas de escuta e de insubordinação, desde que academia e militância se disponham a uma alta dose de reconstrução e criatividade. Ainda em termos spivakianos, afirmo que a academia (e a militância) são parte do problema, e só podem ser parte da solução se estiverem predispostas a desaprenderem os mecanismos de silenciamento do subalterno (MAGGIO, 2007). Em sociedades sexistas e racistas como a brasileira, as pautas feministas não podem renunciar ao racismo como categoria de compreensão da opressão e dos privilégios e das marcas de violência sobre os corpos de mulheres. O que isso significa no contexto do combate à violência de gênero contra mulheres não é definível peremptoriamente. As estratégias e as articulações do poder são cambiantes, e assim devem ser também as estratégias contra-hegemônicas.

Sem pretender solucionar o problema, é entendido aqui que a principal diretriz deve ser buscar as reformas necessárias para que as vítimas de violência sejam valorizadas como protagonistas de seus próprios processos de superação do contexto de violência, com todo o apoio exigido para que não sejam deixadas na precariedade. Decerto, teóricas e militantes precisam investir na produção de mais dados desagregados por raça e classe das vítimas, para saber das discrepâncias e deficiências das políticas públicas, contribuir com a atuação autônoma das redes de mulheres negras, investir no fortalecimento da rede de atendimento - talvez mais do que no monitoramento do Judiciário - e na assistência jurídica qualificada e gratuita, quando o caminho for o judicial.

Nada disso pode ser feito sem a presença desses sujeitos cujos corpos são sistematicamente violentados. A representação desses sujeitos nos espaços de poder, em condições de autonomia e paridade, seja no Estado, seja na academia, seja na sociedade civil, é inegociável se a ideia for abalar minimamente as condições de produção da subalternidade e precisa ser construída com urgência. Isso significa, em especial, um constante autoexame crítico dos privilégios dos quais 
intelectuais e militantes não estão isentas e que dificultam o acesso de mulheres não brancas a esses espaços de poder.

\section{AGRADECIMENTOS}

A autora agradece especialmente a Thula Pires, Carolina Pires, Vanessa do Canto, Adriana Vidal, Mariana Imbelloni Braga e Rodrigo Costa, que tanto ensinaram e construíram, pela parceria tão antiga.Vão constar, sempre, em todas as listas de agradecimentos da autora.

Ela agradece também a todas as alunas e a todos os alunos participantes do grupo de pesquisa "Gênero, Democracia e Direito", e aos que passaram pela disciplina "Raça e Gênero", coministrada por ela e por Thula Pires. A Rosane Reis, Arlanza Ribeiro e Adriana Mello, por partilharem suas experiências no "front" do direito. Às participantes do Simpósio Temático sobre Acesso à Justiça, no Seminário Internacional Fazendo Gênero 11, de 2017, em especial Fabiana Severi, Ela Wiecko e Silvia Pimentel. Ela Wiecko merece um agradecimento muito especial pelo exemplo, pela trajetória e pela honra da parceria. Por fim, agradece ao CNPq e à Fundação de Amparo à Pesquisa do Estado do Rio de Janeiro (Faperj) pelo financiamento que possibilitou a pesquisa com as Medidas Protetivas de Urgência revisitadas neste artigo.

\section{REFERÊNCIAS}

AKOTIRENE, Carla. O que é interseccionalidade? Belo Horizonte: Letramento, 2018.

ALMEIDA, Sandra Regina Goulart. Introdução. In: SPIVAK, Gayatri. Pode o subalterno falar? Belo Horizonte: Editora UFMG, 2010. 
ALMEIDA, Tania Mara Campos; PEREIRA, Bruna Cristina Jaquetto. Violência doméstica e familiar contra mulheres pretas e pardas no Brasil: reflexão pela ótica dos estudos feministas latino-americanos. Crítica e Sociedade: Revista de Cultura Política. Dossiê Cultura e Política, v. 2, n. 2, p. 58-59, dez. 2012.

BARSTED, Leila Linhares. Lei Maria da Penha: uma experiência bem-sucedida de advocacy feminista. In: CAMPOS, Carmen Hein (org.). Lei Maria da Penha - comentada em uma perspectiva jurídico-feminista. Rio de Janeiro: Lumen Juris, 2011. p. 13-42.

BEAUVOIR, Simone de. O segundo sexo. São Paulo: Difusão Europeia do Livro, 1967.

BENTO, Aparecida S.; CARONE, Iray. Psicologia social do racismo. Petrópolis: Vozes, 2016.

BERNARDES, Márcia Nina. Aspectos transnacionais da Lei Maria da Penha. Direito, Estado e Sociedade (Impresso), v. 45, p. 20-40, 2014.

BERNARDES, Márcia Nina. Domestic violence and gender oppression: an analysis of Brazilian law in light of a theory of democratic justice. In: ZIRK-SADOWSKI, Marek; WOJCIECHOWSKI, Bartosz; CERN, Karolina M. (org.). Towards the recognition of minority groups: legal and communication strategies. London: Ashgate Publishing, 2014. v. 1.

BERNARDES, Márcia Nina. Philosophical and jurisprudential issues on domestic violence and gender discrimination. In: GALUPPO, Marcelo et al. (org.). Human rights, rule of law and the contemporary social challenges in complex societies: Proceedings of the XXVIWorld Congress of Philosophy of Law and Social Philosophy. Belo Horizonte: Initia Via, 2015. v. 1.

BERNARDES, Márcia Nina; ALBUQUERQUE, Mariana Imbelloni Braga. Problemas de gênero da jurisprudência brasileira: desfazendo a Lei Maria da Penha. Revista Direito, Estado e Sociedade, n. 55, p. 231-256, 2019.

BERNARDES, Márcia Nina; ALBUQUERQUE, Mariana Imbelloni Braga. Violências interseccionais silenciadas em medidas protetivas de urgência / Intersectional violence silenced in judicial proceedings. Revista Direito e Práxis, v. 7, p. 1-26, 2016.

BERNARDES, Márcia Nina; COSTA, Rodrigo de Souza. Medidas protetivas de urgência e violência contra as mulheres: análise da aplicação da Lei Maria da Penha no Juizado de Violência Doméstica e Familiar contra a Mulher de Niterói. In: SILVA, Marcos Alves da; TAVARES, Silvana Beline (org.). Gênero, sexualidades e direito I. Florianópolis: Conpedi 2016. v. 1. p. 64-84. 
BERNARDES, Márcia Nina; COSTA, Rodrigo de Souza. Os Parâmetros Internacionais de Prevenção da Violência Doméstica contra as Mulheres: uma comparação com os instrumentos previstos na Lei Maria da Penha. In: LOIS, Cecilia Caballero; BRANDÃO, Daniela da Rocha; MEYER-PFLUG, Samantha Ribeiro (org.). Direito internacional dos direitos humanos 1. Florianópolis: Conpedi 2015. v. 1. p. 358-384.

BERNARDES, Márcia Nina; COSTA, Rodrigo de Souza; OLIVEIRA, Adriana Vidal de. Violência doméstica, discriminação de gênero e medidas protetivas de urgência. Curitiba: Juruá, 2016. v. 1.

BERNARDES, Márcia Nina; OLIVEIRA, Adriana Vidal de. As medidas protetivas de urgência: perfil dos procedimentos em tramitação no juizado de violência doméstica e familiar da comarca de Duque de Caxias. In: SILVA, Juvêncio Borges; THIBAU, Tereza Cristina Sorice Baracho; MACHADO, Edinilson Donisete (org.). Acesso à justiça I. Florianópolis: Conpedi 2015. v. 1. p. 434-452.

BRAH, Avtar. Diferenças, diversidades, diferenciação. Cadernos Pagu, n. 26, p. 329-376, jul.-nov. 2006.

BUTLER, Judith. Notes toward a performative theory of assembly. Cambridge: Harvard University Press, 2015.

BUTLER, Judith. Quadro de guerras. London:Verso, 2009.

BUTLER, Judith. Precarious life. London: Verso, 2006.

CAMPOS, Carmen Hein. Lei Maria da Penha, a necessidade de um novo giro paradigmático. Revista Brasileira de Segurança Pública, São Paulo, v. 11, n. 1, p. 10-22, jan.-fev. 2017.

CARDOSO, Lourenço. Branquitude acrítica e crítica: a supremacia racial e o branco antirracista. Revista Latinoamericana de Ciencias Sociales, Niñez y Juventud [on-line], v. 8, n. 1, p. 607-630, 2010.

CARNEIRO, Suelaine Aparecida. Mulheres negras e violência doméstica: decodificando os números. São Paulo: Geledés - Instituto da Mulher Negra, 2017.

CARNEIRO, Sueli. Enegrecer o feminismo: a situação da mulher negra na América Latina a partir da perspectiva de gênero. In: ASHOKA EMPREENDIMENTOS SOCIAIS; TAKANO CIDADANIA (org.). Racismos contemporâneos. Rio de Janeiro: Takano, 2003.

COLLINS, Patricia; BILGE, Sirma. Intersectionality. Cambridge: Polity Press, 2016.

COMISSÃO PARLAMENTAR MISTA DE INQUÉRITO. Relatório Final. Brasília, 2013. Disponível em: http://www.mulher.df.gov.br/wp-conteudo/uploads/2017/11/CPMI-da-Violência-Contra-aMulher-Análise-e-Recomendações-ao-DF-Relatório-final.pdf. Acesso em: 24 set. 2020. 
COSTA, Rodrigo de Souza; OLIVEIRA, Adriana Vidal de. Lei n. 11.340/06 e sistema penal: o quão punitivos são os juizados de violência doméstica e familiar contra a mulher. In: ESTEVES, Juliana Teixeira; BARBOSA, José Luciano Albino; FALCÃO, Pablo Ricardo de Lima (org.). Direitos, gênero e movimentos sociais II. Florianópolis: Conpedi, 2014. v. 1. p. 267-282.

CRENSHAW, Kimberlé. Documento para encontro de especialistas em aspectos da discriminação racial relativos ao gênero. Revista de Estudos Feministas, v. 10, n. 1, 2002.

CRENSHAW, Kimberlé. Mapping the margins: intersectionality, identity politics, and violence against women of color. Stanford Law Review, v. 43, n. 6, July 1991.

CRENSHAW, Kimberlé. Demarginalizing the intersection of race and sex: a black feminist critique of antidiscrimination doctrine, feminist theory, and antiracist politics. University of Chicago Legal Forum, v. 14, p. 538-554, 1989.

DAVIS, Angela. Women, race and class. New York: Ramdom House, 1981.

FlaUZINA, Ana Luiza Pinheiro. Lei Maria da Penha: entre os anseios da resistência e as posturas da militância. In: FLAUZINA, Ana Luiza Pinheiro et al. (org.). Discursos negros: legislação penal, política criminal e racismo. Brasília: Brado Negro, 2015.

FLAUZINA, Ana Luiza Pinheiro et al. Discursos negros: legislação penal, política criminal e racismo. Brasília: Brado Negro, 2015.

FOUCAULT, Michel. História da sexualidade - A vontade de saber. São Paulo: Graal, 2001. v. 1.

FRIEDAN, Betty. The feminine mystique. New York:W.W. Norton \& Company, Inc., 1963.

GONZALEZ, Lélia. Racismo e sexismo na cultura brasileira. Revista Ciências Sociais Hoje, São Paulo: Anpocs, 1984.

HALL, Stuart. Avtar Brah's cartographies: moment, method, meaning. Feminist Review, n. 100, p. 27-38, 2012.

HOOKS, Bell. Feminist theory: from margins to center. Boston: South End Press, 1984.

HOOKS, Bell. Ain't I aWomen: black women and feminism. Boston: South End Press, 1981.

INSTITUTO BRASILEIRO DE GEOGRAFIA E ESTATÍSTICA (IBGE). Pesquisa nacional por amostra de domicílios contínua, 2018. 
INSTITUTO DE PESQUISA ECONÔMICA APLICADA (IPEA). Avaliando a efetividade da Lei Maria da Penha. Brasília, 2015. Disponível em: https://www12.senado.leg.br/institucional/omv/entenda-aviolencia/pdfs/a-efetividade-da-lei-maria-da-penha. Acesso em: 24 set. 2020.

INSTITUTO DE PESQUISA ECONÔMICA APLICADA (IPEA). Atlas daViolência. Brasília, 2019.

LUGONES, Maria. Rumo a um feminismo descolonial. Estudos Feministas, v. 22, n. 3, p. 935-952, set.-dez. 2014.

MAGGIO, J. Can the subaltern be heard? Political theory, translation, representation, and Gayatri Chakravorty Spivak. Alternatives: Global, Local, Political, v. 32, n. 4, p. 419-443, Oct.-Dec. 2007.

MARINHO, Pedro Rennó. Ocupações performativas: moradia, direito e corpos em aliança. Dissertação (Mestrado) - Departamento de Direito da PUC-Rio, Rio de Janeiro, 2019.

MEYERSFELD, Bonita. Domestic violence and international law. Oxford: Hart Publishing, 2010.

MONTENEGRO, Marilia. Lei Maria da Penha: uma análise criminológico-crítica. Rio de Janeiro: Revan, 2015.

PASINATO, Wânia. 10 anos de Lei Maria da Penha. O que queremos comemorar? Sur: Revista Internacional de Direitos Humanos (Impresso), v. 1, 2017.

PEREIRA, Bruna Cristina Jaquetto. Tramas e dramas de gênero e de cor: a violência doméstica contra mulheres negras. Brasília: Brado Negro, 2016.

PIRES, Thula Rafaela de Oliveira. Direitos humanos traduzidos em pretuguês. Transformações, Conexões e Deslocamentos. Seminário Internacional Fazendo Gênero 11 \& 13th Women’s Worlds Congress (Anais Eletrônicos), Florianópolis, 2017. Disponível em: http://www.en.wwc2017.eventos.dype.com.br / resources/anais/1499473935_ARQUIVO_Texto_completo_MM_FG_ThulaPires.pdf. Acesso em: 27 out. 2020.

PIRES, Thula Rafaela de Oliveira. O que significa renunciar a uma categoria? Empório do Direito, 2017. Disponível em: http: / / emporiododireito.com.br/leitura/o-que-significa-renunciar-a-uma-categoria1508244312. Acesso em: 24 set. 2020.

SCHUCMAN, Lia. Entre o encardido, o branco e o branquíssimo: raça, hierarquia e poder na cidade de São Paulo. São Paulo: Fapesp, 2014.

SPIVAK, Gayatri. Pode o subalterno falar? Belo Horizonte: Editora UFMG, 2010. 
SPIVAK, Gayatri. Subaltern talk. In: LANDRY, Donna; MACLEAN, Gerald (org.). The Spivak reader. New York and London: Routledge, 1996.

SPIVAK, Gayatri. Interview to Leon de Kock. New Nation Writers Conference in South Africa. Ariel: A Review of International English Literature, v. 23, n. 3, p. 29-47, July 1992.

WAISELFISZ, Julio Jacobo. Mapa da violência: homicídio de mulheres no Brasil. Flacso Brasil, 2015. Disponível em: http://www.onumulheres.org.br/wp-content/uploads/2016/04/MapaViolencia_2015_ mulheres.pdf. Acesso em: 29 set. 2020.

WERNECK, Jurema; IRACI, Nilza. A situação dos direitos humanos das mulheres negras no Brasil: violências e violações. São Paulo: Criola-Geledés, 2016.

XAVIER, Lúcia. Racismo e desigualdades raciais em tempos de pandemia do novo Coronavírus (COVID 19). Palestra proferida no Curso de Especialização em Direitos Humanos (PUC-Rio e IERRB/MPRJ). Disponível em: https: / / www.youtube.com/watch?v=j0Tm9JHsRi8\&feature=youtu.be. Acesso em: 28 jun. 2020.

\section{COMO CITAR ESTE ARTIGO:}

BERNARDES, Márcia Nina. Questões de raça na luta contra a violência de gênero: processos de subalternização em torno da Lei Maria da Penha. Revista Direito GV, v. 16, n. 3, set./dez. 2020, e1968. doi: http://dx.doi.org/ 10.1590/2317-6172201968.

\section{Márcia Nina Bernardes}

Professora de Direito na Pontifícia Universidade Católica do Rio de Janeiro (PUC-RIO). Doutora em Direito PELA NYU LaW School. Mestre em Direito Pela PUC-Rio e NYU LaW School. Coordenadora do Núcleo de Direitos Humanos do Departamento de Direito da PUC-Rio. Pesquisadora do CNPQ. INTEgRANTE dA REDE LATINO-AMERICANA DE ACAdÊMICOS FEministas (Red ALAS).

marcianblapuc-rio.br 